\title{
STRUCTURAL STEEL ANALYSIS DESIGN OF COMMERCIAL FACTORIES FOR LOADING AND EARTHQUAKE RESISTANCE
}

\author{
Sami N. O. Bakarman \\ Faculty of Engineering \\ Narotama University Surabaya \\ sami20089111@gmail.com \\ Koespiadi \\ Faculty of Engineering \\ Narotama University Surabaya
}

\begin{abstract}
In the university my courses According to the widely used of "Steel buildings " in these days which taught us to analyze and design this flooring system that can achieve the requirements of this structure. Also use several programs like (ETAB, SAP, ROBOT \& TEKLA etc), beside that I used different combinations for earthquake resistance. It analysis and design according to the eurocode AISC 14.0 , in addition to that I used the program of Autodesk Robot Structural, AUTO CAD 2013 \& Tekla Structure. while I have many components I used that program to help me for designing, by include the loads as input, then I got different diagrams and diameters for each part.
\end{abstract}

Keyword : Steel connection \& Loading

\section{INTRODUCTION}

Most design tasks in structural engineering are based both on theoretical models and empirical evidence. The theory is developed into a design procedure, and this procedure is carried out and tested. The results of these tests are then used to formulate new and more accurate analysis procedures. So, to some extent, this is an iterative process.

Centuries of experience with building structures as well as new developments in analytical procedures have led to a greater understanding of how structures work. This is especially true in the area of connections in structures. There is a fairly high degree of uncertainty in the behavior of connections, which makes their analysis and design difficult, and makes experimental verification so important. Many of the elements of the connections have variability in their properties, which, when analyzed together, further increase the uncertainties in the connection. The consequence of this is that careful and accurate design of connections can be crucial to the design of the structure. This thesis attempts to understand and compare various types of connections in structural steel buildings, including both the modeling theory of connections as well as the physical components of connections.

\section{Formulation Of The Problem}

1. How to make the building earthquake resistant?

2. How to make the building static and how to make the building economic and construction products relevant for steel structures?

3. Why we will use claddings working in one-way (horizontal) direction and an analyzed?

\section{AIM}

1. Agree exactly what a project is meant to do and what it is meant to deliver. 
2. Agree the design, timescale, analysis and design and quality of project.

3. Understand and apply methods and approaches adopted by the code regarding the analyzed structure.

4. Comprehend the method of designing steel structures.

5. Establish a link between analysis of structures and the design process.

6. Enhance applying computer package programs such as: ROBOT, AUTOCADE ,TEKLA and Microsoft office to determine the calculation process and obtain the required results.

7. Understand the exact and suitable ways to analyze and design.

8. Prepare myself for work environmental to be an engineer.

\section{LITERATURE REVIEW}

\section{Design of Bolted Connections with Injection Bolts \\ - Design rules for static loading}

As of now demonstrated previously, injection bolts might be non-preloaded load move through bearing and shear of the bolt and furthermore preloaded load move through bearing and shear of the bolt and through grinding between the associated plates. The ECCS proposals give design rules for both types of shear connections.

- Bearing and shear:

The plan extreme shear load shall not surpass the plan shear opposition of the bolt nor the plan bearing obstruction of the resin.

Serviceability limit state:

Ultimate limit state:

$$
F_{b . R d . s e r . r e s i n}=\frac{1 \cdot 0 \cdot K_{s} \cdot d \cdot t \beta \cdot f_{b \cdot r e s i n}}{\gamma_{M s . s e r}}
$$

$$
F_{b . R d . u l t . r e s i n}=\frac{1.2 K_{s} \cdot d t \beta f_{b . r e s i n}}{\gamma_{M s} . u l t}
$$

Shear resistance of the bolt (Eurocode 3, 1992), shear plane through through the shank of the bolt).

$$
F_{v . R d}=\frac{0.5 f_{U b} A_{s}}{\gamma_{M b}} K N
$$

Design Methods for support and Bracing Connections

\section{Accidental activities:}

- Drifted snow decided utilizing Annex B of BS EN 1991-1-3 (see Section 3.3.3).

- Opening of a prevailing opening thought to be closed.

Robustness requirements of BS EN 1991-1-7 and its National Annex

\section{Combination}

Table 1

\begin{tabular}{|l|l|l|}
\hline Action & $\Psi_{0}$ & $\Psi_{1}$ \\
\hline Imposed loads in buildings, category (see EN 1991-1-1) & & \\
\hline Category A: domestic, residential areas & 0.7 & 0.5 \\
\hline Category B: office areas & 0.7 & 0.5 \\
\hline Category C: congregation areas & 0.7 & 0.7 \\
\hline Category D: shopping areas & 0.7 & 0.7 \\
\hline Category E: storage areas & 1.0 & 0.9 \\
\hline Category H: roofs & 0.7 & 0 \\
\hline Snow loads on buildings (see EN 1991-3) & & \\
\hline - for sites located at altitude H $>1$ 000m a.s.1. & 0.70 & 0.50 \\
\hline - for sites located at altitude H 5 1 000m a.s.1. & 0.50 & 0.20 \\
\hline Wind loads on buildings (see (EN 1991-1-4) & 0.5 & 0.2 \\
\hline Temperature (non-fire) in buildings (see EN 1991 -1 -5) & 0.6 & 0.5 \\
\hline
\end{tabular}




\section{Serviceability limit state}

$$
\sum_{j>1} G_{k, j} "+" Q_{k, 1} \sum_{j>1} \Psi_{0, i} Q_{k, i}
$$

Table 2. Suggested limits for vertical deflections

\begin{tabular}{|l|l|}
\hline Vertical deflection & \\
\hline Cantilevers & Length/180 \\
\hline $\begin{array}{l}\text { Beams carrying plaster or other } \\
\text { brittle finish }\end{array}$ & Span/360 \\
\hline $\begin{array}{l}\text { Other beams (except purlins and } \\
\text { sheeting rails) }\end{array}$ & Span/200 \\
\hline Purlins and sheeting rails & $\begin{array}{l}\text { To suit the characteristics of the } \\
\text { particular cladding }\end{array}$ \\
\hline
\end{tabular}

\section{Loading to the Eurocodes:}

Table 3. Suggested limits for horizontal deflections:

\section{Connections}

\begin{tabular}{|l|l|}
\hline Horizontal deflection & \\
\hline $\begin{array}{l}\text { Tops of columns in single-story buildings } \\
\text { except portal frames. }\end{array}$ & Height/300. \\
\hline $\begin{array}{l}\text { Columns in gateway frame structures, } \\
\text { not supporting crane runways. }\end{array}$ & specific cladding. \\
\hline $\begin{array}{l}\text { In every story of a structure with more } \\
\text { than one story. }\end{array}$ & Height of that story $/ 300$. \\
\hline
\end{tabular}

Connections are initially assumed as pins, thereby implying that the centroidal axes of all members intersecting at a node point are coincident. Practical considerations frequently dictate otherwise, and it is quite common for member axes to be eccentric to the assumed node for reasons of fit-up and the physical constraints that are inherent in the truss structure. Such eccentricities induce secondary bending stresses of the node points, which must be accounted for not only by local bending and axial load checks at the ends of all constituent members, but also in connection design. Typical truss joints are illustrated .It is customary to calculate the net bending moment at each node point due to any eccentricities, and proportion this moment to each member connected to the node in relation to member stiffness.

\section{Portal frames}

By far the most common structural form for single-storey buildings is the portal Frame.

Various configurations of portal frame

\section{Table 4}

\begin{tabular}{|l|l|}
\hline Section 4.6 & Preliminary design of portal frames \\
\hline Section 4.7 & Bracing \\
\hline Section 4.8 & $\begin{array}{l}\text { Design of portal frames to BS EN 1993- } \\
1-1 .\end{array}$ \\
\hline
\end{tabular}




\section{Bracing}

Bracing is required to resist lateral loads, principally wind loads, and the destabilising effects of the imperfections defined in Section 5.3 of BS EN 1993-1-1

\section{Bracing at plastic hinges:}

\section{First-order and second-order analysis}

$$
Q_{m}=1.5 a_{m} \frac{N_{f, E d}}{100}
$$

For portal frames with shallow roof slopes, provided that the axial compression in the beams or rafters is not significant and a, , 23,0 the 'amplification factor' can be calculated according to: $\left(\frac{1}{1-1 / a_{c r}}\right)$

\section{Secondary beams:}

Table 5. Beams as secondary beams (IPE/HE sections in S355 steel) of sizes

\begin{tabular}{|l|l|l|l|l|l|}
\hline Cellular beam & \multicolumn{5}{|l}{ Maximum span } \\
\hline & 12 & 13.5 & 15 & 16.5 & 18 \\
\hline $\begin{array}{l}\text { Opening diameter } \\
(\mathrm{mm})\end{array}$ & 300 & 350 & 400 & 450 & 500 \\
\hline Beam depth (mm) & 460 & 525 & 570 & 630 & 675 \\
\hline Top chord & IPE 360 & IPE 400 & IPE 400 & IPE 400 & IPE 450 \\
\hline Bottom chord & $\begin{array}{l}\text { HE 260 } \\
\text { A }\end{array}$ & HE 260 A & $\begin{array}{l}\text { HE 300 } \\
\text { A }\end{array}$ & $\begin{array}{l}\text { HE 3660 } \\
\text { B }\end{array}$ & $\begin{array}{l}\text { HE 40 } \\
\text { M }\end{array}$ \\
\hline
\end{tabular}

Table 6. Composite cellular beams as secondary beams (UC sections in S355 steel) of sizes

\begin{tabular}{|l|c|l|l|l|l|}
\hline \multirow{2}{*}{$\begin{array}{c}\text { Cellular } \\
\text { beam }\end{array}$} & \multicolumn{5}{|c|}{ Maximum span } \\
\cline { 2 - 6 } & 12 & 13.5 & 15 & 16.5 & 18 \\
\hline $\begin{array}{l}\text { Opening } \\
\text { diameter } \\
(\mathrm{mm})\end{array}$ & 300 & 350 & 400 & 450 & 450 \\
\hline $\begin{array}{l}\text { Beam depth } \\
(\mathrm{mm})\end{array}$ & 415 & 490 & 540 & 605 & 625 \\
\hline & $\begin{array}{c}305 \mathrm{UC} \\
54\end{array}$ & $\begin{array}{l}356 \mathrm{UC} \\
67\end{array}$ & $\begin{array}{l}406 \mathrm{UC} \\
67\end{array}$ & $\begin{array}{l}457 \mathrm{UC} \\
67\end{array}$ & $457 \mathrm{UC} 82$ \\
\hline Top chord & $\begin{array}{c}54 \mathrm{UC} \\
305 \mathrm{UC}\end{array}$ & $\begin{array}{l}305 \mathrm{UC} \\
137\end{array}$ & $\begin{array}{l}356 \mathrm{UC} \\
153\end{array}$ & $356 \mathrm{UC} 287$ \\
\hline $\begin{array}{l}\text { Bottom } \\
\text { chord }\end{array}$ & $\begin{array}{c}259 \\
54\end{array}$ & & & \\
\hline
\end{tabular}

\section{Tension members}

tension member (or tie) transmits a direct tensile force

$$
N_{p l, R d}=\frac{A f_{y}}{\gamma_{M 0}} \quad, \quad N_{u, R d}=\frac{0.9 A_{n e t} f_{u}}{\gamma_{M 2}}
$$

\section{Columns and struts}

Members subject to compression are typically referred to as either columns

$$
N_{c r}=\frac{A f_{y}}{N_{c r}} \quad, \quad N_{c r}=\frac{\pi^{2} E I}{L_{c r}^{2}}
$$

\section{Column buckling resistance}

Is a function of its slenderness, its material strength, cross-sectional shape and method of manufacture. Using BS EN 1993-1-1, column buckling resistance

$\boldsymbol{N}_{\boldsymbol{P l}, \boldsymbol{R} \boldsymbol{R}}=\frac{\chi A f_{\boldsymbol{y}}}{\gamma_{M 1}} \quad$ for class 1,2 and 3 sections ,

$N_{b, R d}=\frac{\chi A_{\text {eff }} f_{y}}{\gamma_{M 1}} \quad$ for class 4 sections

buckling reduction factor defined

$$
\chi=\frac{1}{\Phi+\sqrt{\Phi^{2}-\bar{\lambda}^{2}}} \leq 1.0
$$




$$
\Phi=0.5\left[1+a(\overline{\lambda-0.2})+\bar{\lambda}^{2}\right]
$$

Table 7. Imperfection factors a

\begin{tabular}{|l|c|l|l|l|l|}
\hline Buckling curve & ? & a & b & c & d \\
\hline $\begin{array}{l}\text { Imperfection factor } \\
\text { a }\end{array}$ & 0.13 & 0.21 & 0.34 & 0.49 & 0.78 \\
\hline
\end{tabular}

\section{Beams}

Beams are possibly the most fundamental type of member present in a civil engineering structure

\section{S355 steel:}

\begin{tabular}{|l|l|l|}
\multicolumn{2}{|c|}{$\begin{array}{l}\text { span range } \\
\text { beam type }\end{array}$} & nable .8 \\
\hline Angles & $1-6$ & $\begin{array}{l}\text { Used for roof purlins, sheeting rails, etc. } \\
\text { where only light loads have to be carried }\end{array}$ \\
\hline $\begin{array}{l}\text { Cold-formed } \\
\text { sections }\end{array}$ & $2-8$ & $\begin{array}{l}\text { Used for roof purlins, sheeting rails, etc. } \\
\text { where only light loads have to be carried }\end{array}$ \\
\hline $\begin{array}{l}\text { Rolled sections: } \\
\text { UBs,IPEs, UCs, } \\
\text { Hes }\end{array}$ & $1-30$ & $\begin{array}{l}\text { Most frequently used type of section; } \\
\text { proportioned to eliminate several possible } \\
\text { modes of failure }\end{array}$ \\
\hline Open web joists & $4-40$ & $\begin{array}{l}\text { Prefabricated using angles or tubes as chords } \\
\text { and round bar for the web diagonals, used in } \\
\text { place of rolled sections }\end{array}$ \\
\hline Cellular beams & $6-60$ & $\begin{array}{l}\text { Used for long spans and/or light loads; depth } \\
\text { of rolled section increased by 50\%; web } \\
\text { openings may be used for services etc. }\end{array}$ \\
\hline Compound & $5-30$ & $\begin{array}{l}\text { Used when a single rolled section would not } \\
\text { provide } \\
\text { sufficient resistance }\end{array}$ \\
\hline sections & $10-100$ & $\begin{array}{l}\text { Made by welding 3 plates, often } \\
\text { automatically, with web depths up to 3-4 m; } \\
\text { may need stiffening - see Chapter 18 }\end{array}$ \\
\hline Plate girders & $15-100$ & $\begin{array}{l}\text { Fabricated from angles, tubes or, if spanning } \\
\text { large } \\
\text { distances, rolled sections - see Chapter 20 }\end{array}$ \\
\hline Trusses & $\begin{array}{l}\text { Fabricated from plate, usually stiffened; used } \\
\text { for overhead travelling cranes and bridges } \\
\text { due to good torsional and transverse stiffness } \\
\text { properties }\end{array}$ \\
\hline Box girders & $15-200$ & \\
\hline
\end{tabular}

All but 1 Universal Beams are Class 1 (1 is Class 2). All but 6 Universal Columns are Class 1 ( 3 are Class 2,3 are

$$
M_{c, R d}=\frac{W_{p l} f_{y}}{\gamma_{M 0}} \quad, \quad M_{c, r d}=\frac{W_{e l} f_{y}}{\gamma_{M 0}}
$$

Determination of beam slenderness $\bar{\lambda}_{L T}$

$$
\varepsilon=\sqrt{235 / f_{y}}
$$

Hence, lateral torsional buckling resistance $M_{b, R d}$ is given by:

$$
M_{b, R d}=\frac{x_{L T} W_{y} f_{y}}{\gamma_{M 1}}
$$

$M_{c r}=C_{1} \frac{\pi^{2} E I_{z}}{L_{c r}^{2}} \sqrt{\frac{I_{w}}{I_{z}}+\frac{L_{c r}^{2} G I_{t}}{\pi \pi^{2} E I_{z}}}$

\section{Bolted connections}

For many years, riveting was the accepted method used for connecting the members of steel structures 
Table. 9

\begin{tabular}{|c|c|c|c|c|}
\hline $\begin{array}{l}\text { Bolt } \\
\text { Diameter }\end{array}$ & $\begin{array}{l}\text { Standard } \\
\text { (Dia) }\end{array}$ & $\begin{array}{l}\text { Oversize } \\
\text { (Dia) }\end{array}$ & $\begin{array}{l}\text { Short-slot } \\
\text { (width X Length) }\end{array}$ & $\begin{array}{l}\text { Long slot } \\
\text { (Width X Length) }\end{array}$ \\
\hline 12 & ${ }^{9} 16$ & ${ }^{5} 8$ & ${ }^{9}{ }_{16} \stackrel{n}{11}_{16}^{11}$ & ${ }_{16} ?^{n} 1_{4}^{1}$ \\
\hline${ }^{5} 8$ & $11 \quad 16$ & 1316 & $11{ }_{16} ?^{7}{ }^{7} 8$ & ${ }_{11}{ }_{16} ? 1^{9}{ }_{16}$ \\
\hline $3_{4}$ & $13 \quad 16$ & 1516 & ${ }_{16}{ }^{? ? 1}$ & ${ }^{13} 16 ?^{? ? 1^{7}} 8$ \\
\hline${ }^{7} 8$ & ${ }^{15}{ }_{16}$ & ${ }^{1}{ }_{16}$ & ${ }^{15}{ }_{16} ? ?^{1}{ }^{1} 8$ & ${ }^{15} 16 ? 2^{3} 16$ \\
\hline 1 & $1^{1} 16$ & $1_{4}^{1}$ & ${ }^{1}{ }_{16} ? ?^{5}{ }_{16}$ & $1_{16}^{1}{ }^{? ? 2^{1}} 2$ \\
\hline$=1^{1} 8$ & $?++^{1} 16$ & $\begin{array}{ll} & \\
& \\
+ & \\
+ & \\
& 16 \\
\end{array}$ & $\begin{array}{r}?+116 ? ? ? \\
+{ }^{3} 8 \\
\end{array}$ & $\begin{array}{llll}? & & & \\
+ & 1 & & \\
+ & \text { ?. } & 2.5 & \text { ??? } \\
\end{array}$ \\
\hline
\end{tabular}

Bearing-Type connections (Bearing strength):

$\checkmark$ If deformations around bolt holes is a design consideration (that is, if we want deformations to be $\leq 0.25$ in ), that

$$
R_{n}=1.2 l_{c} F_{u} \leq 2.4 d t F_{u}
$$

$\checkmark$ If deformation around bolt holes is not a design consideration ( that is, if deformations > 0.25 in are acceptable )

$$
R_{n}=1.5 l_{c} F_{u} \leq 3.0 d t F_{u}
$$

$\checkmark$ For bolts used in connections with long-slotted holes, the slots being perpendicular to the forces.

$$
R_{u}=1.0 l_{c} t F_{u} \leq 2.0 d t F_{u}
$$

\section{RESEARCH METHODOLOGY}

Type of use - residential building;

Span $-\mathrm{L}=6 \mathrm{~m}$;

Bay $-\mathrm{B} 1=6 \mathrm{~m}, \mathrm{~B} 2=6 \mathrm{~m}$;

1. Building size: $337.9 \mathrm{~m}^{2}$

2. Total plot area $=425.1 \mathrm{~m}^{2}$

3. Percentage of free space $=3 \sim 4 \%$

4. Location in North Cyprus - Turkey - Near East University.

5. Grade of concrete - C30 - S420, S220 STIRRUBS (MPA)

6. Ground Floor height $400 \mathrm{~cm}$.

7. Slab thickness $\mathrm{t}=20 \mathrm{~cm}$.

8. $\quad$ Type of column $=\mathrm{W} 10 \times 88$

9. Type of Beam $=W 8 \times 58$

10. Type of slab beam $=\mathrm{W} 8 \times 40$

11. Type of Purlin (1) $=$ MC10×33.6

12. Type of Purlin $(2)=L 8 \times 6 \times 1$

13. Type of Brace $=$ PIPE10STD

14. Live load on $\mathrm{slab}=3.0 \mathrm{t} / \mathrm{m}^{2}-$

15. Dead load $=0.15 \mathrm{t} / \mathrm{m}^{2}$

16. Site located on Seismic Zone 2 .

Scheme of the building is given on the following visualization: 


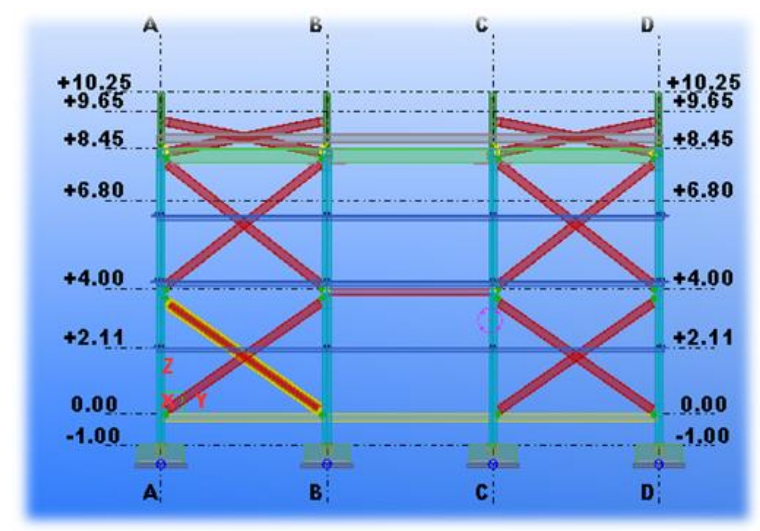

Fig. 1

\section{Structural analysis}

The structural model for the analysis was created in software ROBOT. Following input data is used for model consideration:

- Beams in plane $x z$ are rigidly connected to the steel columns.

- The beams in plane yz are hinged at both ends. Releases for hinged connections are indicated in following directions: Ry, Rz.

- Elements defining bracing system are also hinged at both ends.

- Supports are pinned. Fixed directions of pinned support: Ux, Uy, Uz, Rz.11

- Bracings in axis A1-A2, D1-D2, A3-A4, D3-D4 are represented by one bar per frame assuming that it will work in tension and compression.

- The concrete slab has a strong influence on the global stiffness of the structure. In ROBOT 3D model concrete slab was modeled by a horizontal bracing system, connected to main columns. Connection of these bracings are hinged.

- To identify the type of analysis which should be performed (1st or 2nd order) we calculate $a_{c r}$ for ultimate limit state combinations.

In all combinations $a_{c r}>10$. Therefore, according to EN 1993-1-1 1st order elastic analysis should be performed.

MATERIAL:

\section{ASTM A36 STEEL PLATE}

CHARACTERISTICS

ASTM A36 plate is a low carbon steel that exhibits good strength coupled with formability. It is easy to machine and fabricate and can be securely welded.

A36 STEEL PLATE SIZES

$3 / 16 "-28 "$

TYPICAL CHEMICAL PROPERTIES

Table 10

\begin{tabular}{|l|l|}
\hline Carbon, Max \% & 0.026 \\
\hline Manganese, Max \% & 0 \\
\hline Phosphorus, Max \% & 0.04 \\
\hline Sulphur, Max \% & 0.05 \\
\hline Silicon, Max \% & 0.4 \\
\hline Copper, Max \% & 0.20 \\
\hline
\end{tabular}


ASTM A36 BEAM

ASTM A36 beam is an intermediate tensile strength carbon steel that is easy to form, machine and weld

$\checkmark$ TYPICAL MECHANICAL PROPERTIES

Table 11

\begin{tabular}{|l|l|}
\hline Ten sile Strength, ksi & $58-80$ \\
\hline Yield Point, ksi & 36 \\
\hline
\end{tabular}

ASTM A36 CHANNEL

ASTM A36 is a hot-rolled, low-alloy carbon steel that exhibits good tensile strength. Its properties include ductility, ease of machinability and welding.

\section{SIZES}

Depths: $0.5 "$ thru 18"

Flange Widths: 0.125" thru 5"

TYPICAL MECHANICAL PROPERTIES

Table 12.

\begin{tabular}{|l|l|}
\hline Yield Point ksi, min & $36 \mathrm{~min}$ \\
\hline Tensile Strength ksi & $58-80$ \\
\hline \% Elong. 2" Bend & 23 \\
\hline
\end{tabular}

Table 13. Flowchart Of Project

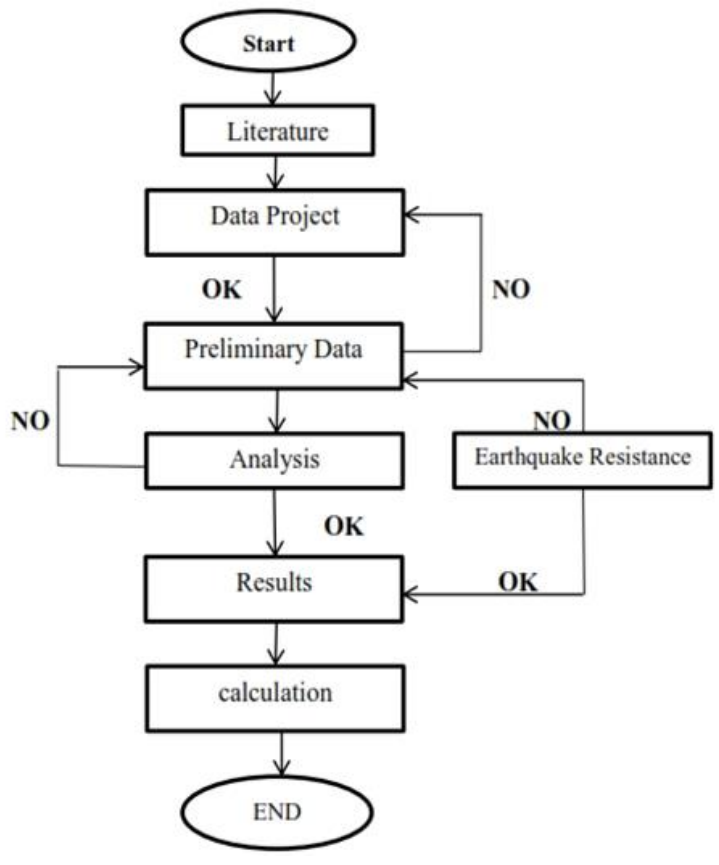




\section{DRAWING BY TEKLA}

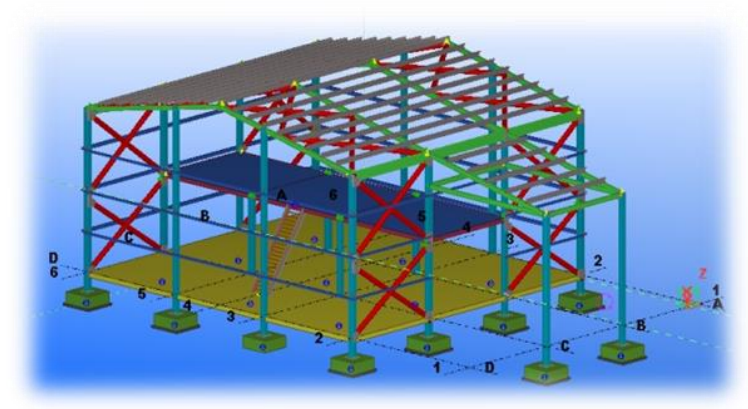

Fig 2

\section{RESULTS AND DISCUSSION}

\section{Structural analysis}

- Beams in plane $x z$ are rigidly connected to the steel columns.

- The beams in plane yz are hinged at both ends. Releases for hinged connections are indicated in following directions: Ry, Rz.

\section{Table .14}

\begin{tabular}{|l|l|l|}
\hline & & Limit values \\
\hline beam-to-column & W8x58 - W10x88 & 0.26 \\
\hline beam-to-beam & W8x58 - & 0.98 \\
\hline beam-column (web) connection & W8x58 - W10x88 & 0.54 \\
\hline Fixed Column base design & W10x88 & 0.87 \\
\hline Bracing & PIPE10STD & \\
\hline Horizontal deflection $(\Delta)$ & 2 & 2.4 \\
\hline Horizontal deflection first floor $(\delta 1)$ & 1.3 & 1.33 \\
\hline Bolt bearing on the beam Direction $x$ & & 2.50 \\
\hline & & 0.69 \\
\hline Bolt bearing on the beam Direction $\mathrm{z}$ & & 2.50 \\
\hline & & 0.81 \\
\hline
\end{tabular}

Bracings in axis A1-A2, D1-D2, A3-A4, D3-D4 are represented by one bar per frame assuming that it will work in tension and compression

Table. 15

\begin{tabular}{|l|l|}
\hline & $a_{c r}$ (mode 1) \\
\hline Combination 1 & 10.95 \\
\hline Combination 2 & 10.95 \\
\hline Combination 3 & 11.46 \\
\hline Combination 4 & 11.46 \\
\hline Combination 5 & 11.66 \\
\hline Combination 6 & 11.66 \\
\hline
\end{tabular}

- Design of fixed beam-to-column connection ( Frame knee connections )

Weakest component:

BOLT RUPTURE

Remarks 


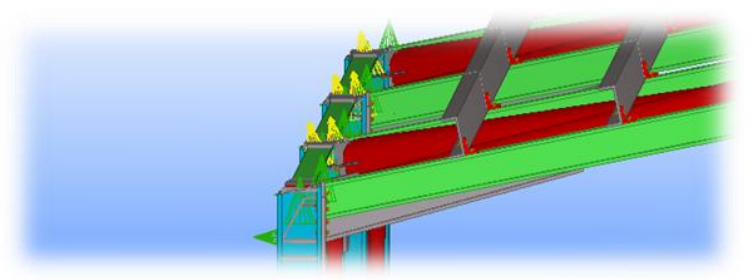

Fig3

The thickness of bracket web is less than the thickness of beam web $8[\mathrm{~mm}]<13[\mathrm{~mm}]$

The thickness of bracket flange is less than the thickness of beam flange $12[\mathrm{~mm}]<21[\mathrm{~mm}]$

Table .16

\begin{tabular}{|l|l|}
\hline Beam resistances & 0.01 \\
\hline Column resistances & 0.14 \\
\hline $\begin{array}{l}\text { Connection resistance for } \\
\text { compression }\end{array}$ & 0.07 \\
\hline Connection resistance for bending & 0.26 \\
\hline Connection resistance for shear & 0.02 \\
\hline Weld resistance & 24.30 \\
& 24.20 \\
\hline
\end{tabular}

Table .17 SUMMARY TABLE OF FORCES

\begin{tabular}{|c|c|c|c|c|c|c|c|}
\hline $\mathrm{Nr}$ & $F_{\mathrm{t} t \text { Rd }}$ & $F_{t t c, R d}$ & $\mathrm{~F}_{\text {twe,Ro }}$ & $\mathrm{F}_{\text {top }, R \mathrm{~d}}$ & $\mathrm{~F}_{\mathrm{twb}, \mathrm{Ro}}$ & $\mathrm{F}_{\text {tRo }}$ & $\mathrm{B}_{p, \mathrm{Rc}}$ \\
\hline 1312 & 117.99 & 117.99 & 380.85 & 117.99 & 347.67 & 117.99 & 574.39 \\
\hline 2242 & 91.50 & 117.99 & 380.85 & 117.99 & 347.67 & 117.99 & 574.39 \\
\hline 3142 & 53.67 & 117.99 & 380.85 & 117.99 & 347.67 & 117.99 & 574.39 \\
\hline 492 & 34.75 & 117.99 & 380.85 & 117.99 & 347.67 & 117.99 & 574.39 \\
\hline 542 & 15.83 & 117.99 & 380.85 & 117.99 & 347.67 & 117.99 & 574.39 \\
\hline
\end{tabular}

- Design of fixed beam-to-beam connection

Weakest component

FRONT PLATE - TENSION

Remarks

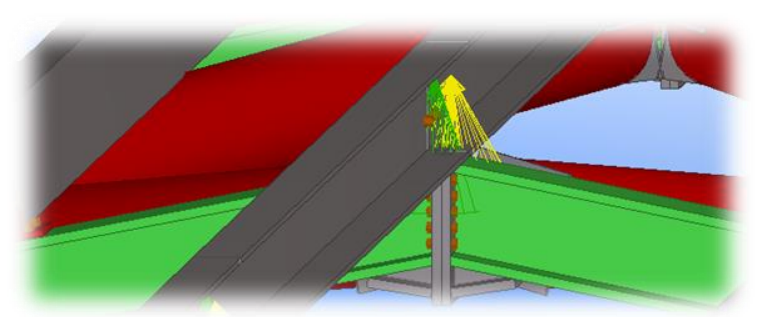

Fig 4

Distance of bolts from an edge is too small

Bolts vertical spacing is too small.

$$
20[\mathrm{~mm}]<20[\mathrm{~mm}]
$$

$35[\mathrm{~mm}]<37[\mathrm{~mm}]$ 


\section{Table . 18}

\begin{tabular}{|l|l|}
\hline Beam resistances & 0.00 \\
\hline Connection resistance for compression & 0.03 \\
\hline Connection resistance for bending & 0.98 \\
\hline Connection resistance for shear & 0.00 \\
\hline Weld resistance & 97.03 \\
& 97.3 \\
& 48.52 \\
\hline
\end{tabular}

\section{SUMMARY TABLE OF FORCES}

The remaining bolts are inactive (they do not carry loads) because resistance of one of the connection components has been used up or these bolts are positioned below the Table . 15

Table 19 center of rotation

\begin{tabular}{|c|c|c|c|c|c|c|c|}
\hline $\begin{array}{ll}\mathrm{Nr} & \mathrm{h}_{\mathrm{J}}\end{array}$ & $F_{t, R d}$ & $F_{\text {tta, Rd }}$ & $\mathrm{F}_{\mathrm{twc}, \mathrm{Rd}}$ & $\mathrm{F}_{\text {top Rd }}$ & $\mathrm{F}_{\mathrm{twb}, \mathrm{Ra}}$ & $\mathrm{F}_{\mathrm{tRd}}$ & $B_{p, R d}$ \\
\hline 1151 & 117.99 & - & - & 117.99 & 549.70 & 117.99 & 574.39 \\
\hline 2116 & 90.67 & - & - & 117.99 & 549.70 & 117.99 & 574.39 \\
\hline 381 & 63.35 & - & - & 117.99 & 549.70 & 117.99 & 574.39 \\
\hline 446 & 36.03 & - & - & 117.99 & 549.70 & 117.99 & 574.39 \\
\hline $5-34$ & - & - & - & 117.99 & - & 117.99 & 574.39 \\
\hline $6-84$ & - & - & - & 117.99 & - & 117.99 & 574.39 \\
\hline
\end{tabular}

- Calculation of the beam-column (web) connection Remarks

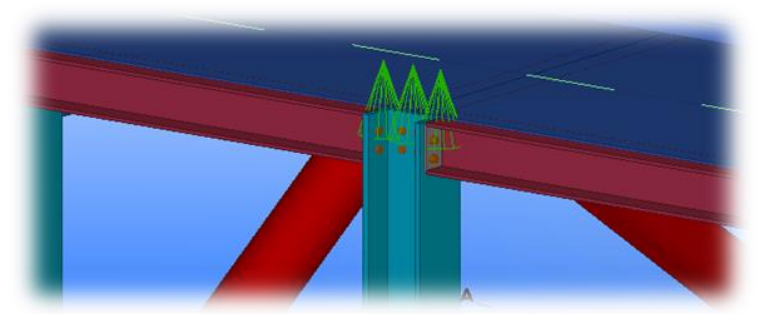

Fig 5

Distance between plate horizontal edge and beam upper flange is too small $21[\mathrm{~mm}]<30[\mathrm{~mm}]$

Length of plate connecting the beam is too large $180[\mathrm{~mm}]>161[\mathrm{~mm}]$

Distance between bolt and edge of beam flange is too small $21[\mathrm{~mm}]<26[\mathrm{~mm}]$

Distance between bolt and plate horizontal edge is too small $20[\mathrm{~mm}]<20[\mathrm{~mm}]$ 


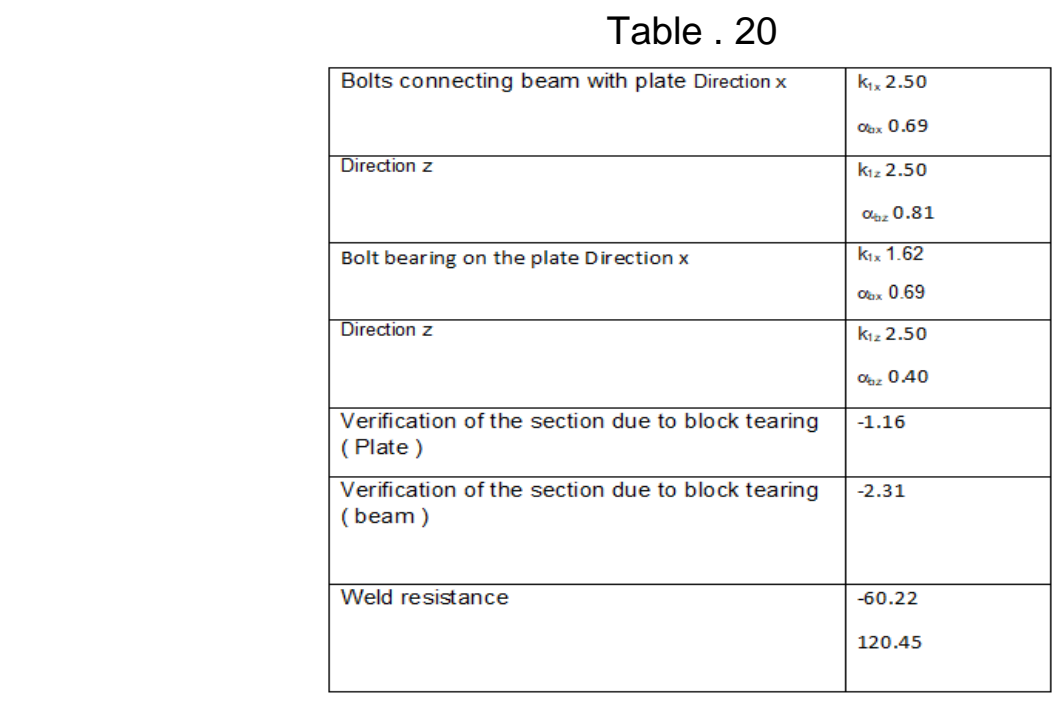

Weakest component:

- Fixed column base design

BASE PLATE - BENDING

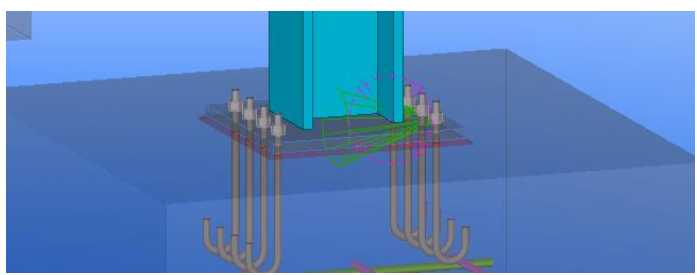

Fig 6

Table . 21

\begin{tabular}{|l|l|}
\hline Connection capacity & 0.87 \\
\hline SHEAR & 0.16 \\
\hline Welds between the column and the base plate & 0.09 \\
\hline
\end{tabular}

\section{CONCLUSION}

Finally, I am going to summary what we have done in this project during the semester briefly:

1. Each student had his own dimensions of the construction then we learnt how to use ETAB program to design the buildings but I used ROBOT program instead of ETAB because I am familiar with ROBOT in addition both programs have the same functions after that we moved to another step which is putting the loads in the program (all the loads), after loading process we had learnt how to design the connection by using ROBOT program and we did so for our building actually it was sensitive step because the safety of construction depends on connection safety mainly

2. Then we used TEKLA program to draw the project after that we converted our drawings from TEKLA program to AUTOCAD program.

3. At the end, we had used four programs we got too much benefit from these programs and by finishing this project now we are qualified to work and design with a real projects but we still need more experience. 


\section{REFERENCES}

[1]. Williams, A.L.A.N. (1975). Structural Engineering Reference Manual.

[2]. American institute of steel construction, chicago, ill. (1986). Load and Resistance Factor Design Specification for Structural Steel Buildings. Retrieved 20 July, 2019.

[3]. Eurocode 3, 1992), . (1992). Load and Resistance Factor DEurocode 3, 1992), esign Specification for Structural Steel Buildings. Retrieved 20 July, 2019.

[4]. Larry s muir, pe aisc atlanta, ga). (AISC (C) 2014, American ). Institute of Steel Construction, Vertical Bracing ConnectionsAnalysis and Design. Retrieved 20 July, 2019. ( brettle m e and brown d g. (2009). Steel Building Design: Concise Eurocodes $\mathrm{SCl}$ publication P362 Ascot, Steel Construction Institute.

[5]. Department for communities and local government.(2006). Steel BuildinGuide to the use of EN 1990 Basis of Structural Designg Design: Concise Eurocodes SCI publication P362 Ascot, Steel Construction Institute. (Dr. Seshu Adluri, Structural Steel Design Compression Members).

[6]. EN 1993-1-5 (2006) (English): Eurocode 3: Design of steel structures - Part 1-5: General rules - Plated structural elements [Authority: The European Union Per Regulation 305/2011, Directive 98/34/EC, Directive 2004/18/EC].

[7]. Maria gulbrandsen rasmus petersen group b-204d. (2013). Advanced Analysis of Steel Structures Master Thesis.

[8]. Enyu liu. (2016). System Reliability-Based Design of Three-Dimensional Steel Structures by Advanced Analysis . Retrieved 22 July, 2019.

[9]. Tongji university. (2016). Structural Analysis and Design of Commercial Building for Earthquake Resistance. Retrieved 07 June 2016, from https://www.researchgate.net/publication/303818187.

[10]. Wlee shoemaker, pe, phd. (2002). Steel design guide series.

[11]. Researchgatenet. (2019). ResearchGate. Retrieved 22 July, 2019, from https://www.researchgate.net/publication/325396329_Boolean_Decision_Rules_via_ Column_Generation.

[12]. T caltrars. (2015). CONCRETE COLUMNS. In Ct caltrars(Ed), BRIDGE DESIGN PRACTICE.

[13]. Msuedu. (2019). Msuedu. Retrieved 22 July, 2019, from https://www.egr.msu.edu/ harichan/classes/ce405/chap4.pdf.

[14]. Prof-engnet. (2019). مدونة المهنس المحترف. Retrieved $22 \quad$ July, 2019, from https://www.prof-eng.net/2016/04/blog-post_18.html.

[15]. Slidesharenet. (2019). Slidesharenet. Retrieved $22 \quad$ July, 2019, from https://www.slideshare.net/Karim.Sayed/steel-1-layout-design-of-sections.

[16]. Cribdcom. (2019). Scribd. Retrieved 22 July, 2019, from https://www.scribd.com/doc/91948140/محاضرات_انشاءات_معدنية_-سعد-الدين-مصطفي.

[17]. Gulf-upcom. (2019). Gulf-upcom. Retrieved 22 July, 2019, from https://www.gulfup.com/9fd5xjac98e8/كتاب الأساسات ـ المهندس عماد درويش.

[18]. Academiaedu. (2019). Academiaedu. Retrieved 22 July, 2019, from https://www.academia.edu/29952420/دليل_التفاصيل_الإنشائيةقى_الكود_المصرى.

[19]. Slidesharenet. (2019). Slidesharenet. Retrieved $22 \quad$ July, 2019, from https://www.slideshare.net/Karim.Sayed/steel-1-layout-design-of-sections. 